\title{
Synthesis, Structural, Spectroscopic, Thermal, Optical Studies and Hirshfeld Surface Analysis of a New Aluminum Complex: $\left(\mathrm{C}_{8} \mathrm{H}_{9} \mathrm{~N}_{2}\right)_{3}\left[\mathrm{Al}\left(\mathrm{C}_{2} \mathrm{O}_{4}\right)_{3}\right] \cdot 3 \mathrm{H}_{2} \mathrm{O}$
}

\author{
Amal Arouri' ${ }^{1}$ Rihab Dridi' ${ }^{1}$, Laurent Jouffret ${ }^{2}$, Mohamed Faouzi Zid1 ${ }^{*}$ \\ ${ }^{1}$ Laboratory of Materials, Crystal Chemistry and Applied Thermodynamics, Faculty of Sciences of Tunis, University of Tunis El \\ Manar, Tunis, Tunisia \\ ${ }^{2}$ Clermont Auvergne University, Clermont-Ferrand, France \\ Email: *faouzi.zid@fst.rnu.tn
}

How to cite this paper: Arouri, A., Dridi, R., Jouffret, L. and Zid, M.F. (2019) Synthesis, Structural, Spectroscopic, Thermal, Optical Studies and Hirshfeld Surface Analysis of a New Aluminum Complex: $\left(\mathrm{C}_{8} \mathrm{H}_{9} \mathrm{~N}_{2}\right)_{3}\left[\mathrm{Al}\left(\mathrm{C}_{2} \mathrm{O}_{4}\right)_{3}\right] \cdot 3 \mathrm{H}_{2} \mathrm{O}$. Crystal Structure Theory and Applications, 8, 29-43. https://doi.org/10.4236/csta.2019.83003

Received: July 18, 2019

Accepted: August 28, 2019

Published: August 31, 2019

Copyright $\odot 2019$ by author(s) and Scientific Research Publishing Inc. This work is licensed under the Creative Commons Attribution International License (CC BY 4.0).

http://creativecommons.org/licenses/by/4.0/

(c) (i) Open Access

\begin{abstract}
The compound, tris-(5-methylbenzimidazole) tris-(oxalato)-aluminate (III) trihydrate, $\left(\mathrm{C}_{8} \mathrm{H}_{9} \mathrm{~N}_{2}\right)_{3}\left[\mathrm{Al}\left(\mathrm{C}_{2} \mathrm{O}_{4}\right)_{3}\right] \cdot 3 \mathrm{H}_{2} \mathrm{O}$, was synthesized by slow evaporation at room temperature and characterized by single crystal $\mathrm{X}$-ray diffraction and $\mathrm{X}$-ray powder diffraction, infrared (IR), ultraviolet (UV-visible) spectroscopies, and thermal analysis. The results show that this complex crystallizes in the monoclinic system, space group $\mathrm{P} 2{ }_{1} / \mathrm{c}$, with the mesh parameters $\mathrm{a}=$ 13.499(7) $\AA, \mathrm{b}=14.872(9) \AA, c=16.995(5) \AA, \beta=91.44(3)^{\circ}, \mathrm{V}=3411(3) \AA^{3}$ and $\mathrm{Z}=4$. The formula unit is composed of tris-(oxalato)-aluminate $\left[\mathrm{Al}\left(\mathrm{C}_{2} \mathrm{O}_{4}\right)_{3}\right]^{3-}$ anions, tris-(5-methylbenzimidazole) cations and three uncoordinated water molecules. The geometry of the aluminum ion is octahedral, formed by six oxygen atoms belonging to three oxalate anions serving as chelating ligands. Cohesion of the structure is ensured by intermolecular hydrogen bonds of $\mathrm{O}-\mathrm{H} . . . \mathrm{O}, \mathrm{N}-\mathrm{H} . . . \mathrm{O}$ type linking ionic entities and water molecules as well as by $\pi-\pi$ and $\pi$ - $\pi^{*}$ between cycles of 5 -methylbenzimidazole cations. In order to clarify the intermolecular interactions formed by the organic cations and inorganic anions, an analysis of the calculated Hirshfeld surfaces was used. The UV-Vis spectrum reveals an optical band gap width of $2.88 \mathrm{eV}$, which shows that this compound has a semiconductor material behavior.
\end{abstract}

\section{Keywords}

Aluminum (III) Complex, Crystal Structure, X-Ray Analysis, Spectroscopic Studies, Thermal Analysis, Hirshfeld Surface Analysis, Semiconductor Material 


\section{Introduction}

The design and fabrication of novel multifunctional hybrid compounds are now attracting increasing interest due to their broad applications in catalysis, evolution of organic materials-inorganic materials, electrochemistry, photochemistry, etc. [1] [2] [3] [4]. In fact, aluminum-based compounds (III) have been used in biology, industry, medicine and even in agriculture [5] [6] [7] [8].

On the other hand, the oxalate group presents an excellent connector ligand for the complexation with different metal ions and a good hydrogen-bonding participant giving rise to different dimensional structures [9]. Moreover, the organometallic compounds based on oxalato ligands have been studied intensively in coordination chemistry. The 5-methylbenzimidazole cation has shown up as an excellent template for building up supramolecular systems and for participating in hydrogen bonding interactions due to its donor/acceptor protons.

In that sense, we have focused our attention on the combination of this cation with aluminum metal ion and oxalic acid. It seemed interesting to investigate the structural, optical, and thermal, of our unreported complex when associating with 5-methylbenzimidazole ligands.

Within this context, we report a chemical synthesis, structural characterization by single crystal X-ray diffraction, vibrational study by infrared spectroscopy, optical and thermal properties of a new hybrid compound namely, tris-(5-methylbenzimidazole) tris-(oxalato)-aluminate (III) trihydrate. Hirshfeld surface analysis was also performed.

\section{Experimental}

\subsection{Materials and Methods}

All chemicals and solvents used in the isolation were obtained from Sigma Aldrich and used without further purification.

The diffraction data was performed using an Enarf-Nonius FR590 four-circle kappa geometry diffractometer type scintillation detector with graphite monochromator using Mo $\mathrm{K} \alpha(\lambda=0.71073 \AA$ ) radiation.

$\mathrm{X}$-ray powder diffraction measurements were performed on a "PAN-analytical, X'pert PRO MPD" diffractometer using $\mathrm{K} \alpha 1(\mathrm{Cu})(\lambda=1.5406$ $\AA$ ) radiation.

The infrared spectrum of the title compound, made on a pellet containing the crushed product dispersed in a $\mathrm{KBr}$ matrix (approximately $4 \%$ by mass of the sample to be analyzed) at room temperature, was recorded using Perkin Elmer Spectrum spectrophotometer in the range of $4000-400 \mathrm{~cm}^{-1}$.

The UV-visible absorption spectrum was recorded on a 2802 UV/VIS spectrophotometer (UNICO).

The thermal analysis (TGA-DTA) was carried out under a helium atmosphere at a heating rate of $10^{\circ} \mathrm{C} \mathrm{m^{-1 }}$ in the temperature range $\left[35^{\circ} \mathrm{C}\right.$ to $\left.600^{\circ} \mathrm{C}\right]$ using a SETARAM brand thermogravimetric analyzer type SETSYS 1750. 


\subsection{Synthesis of $\left(\mathrm{C}_{8} \mathrm{H}_{9} \mathrm{~N}_{2}\right)_{3}\left[\mathrm{Al}\left(\mathrm{C}_{2} \mathrm{O}_{4}\right)_{3}\right] \cdot 3 \mathrm{H}_{2} \mathrm{O}$}

The complex $\left(\mathrm{C}_{8} \mathrm{H}_{9} \mathrm{~N}_{2}\right)_{3}\left[\mathrm{Al}\left(\mathrm{C}_{2} \mathrm{O}_{4}\right)_{3}\right] \cdot 3 \mathrm{H}_{2} \mathrm{O}$ was prepared by adding an amount of oxalic acid dihydrate $\mathrm{H}_{2} \mathrm{C}_{2} \mathrm{O}_{4} \cdot 2 \mathrm{H}_{2} \mathrm{O}$ (99.5\% purity) ( $2 \mathrm{mmol}, 252.2 \mathrm{mg}$ ) in an aqueous solution of aluminum nitrate nonahydrate $\mathrm{Al}\left(\mathrm{NO}_{3}\right)_{3} \cdot 9 \mathrm{H}_{2} \mathrm{O}$ (98\% purity) (1 mmol, $212.99 \mathrm{mg}$ ) and 5-methylbenzimidazole $\left(\mathrm{C}_{8} \mathrm{H}_{8} \mathrm{~N}_{2}\right)$ (98\% purity) (1 mmol, $132.66 \mathrm{mg}$ ), each one has dissolved in $10 \mathrm{~cm}^{3}$ of water under magnetic stirring at room temperature for 30 minutes. The resulting aqueous solution was filtered. After 2 weeks of slow evaporation at room temperature, the colorless prismatic crystals were obtained with a quality judged exploitable in X-ray diffraction.

\section{Results and Discussion}

\subsection{Single Crystal $x$-Ray Diffraction}

A colorless prismatic crystal was selected under a polarizing microscope for single crystal X-ray diffraction analysis. The raw diffraction data were collected using the EXPRESS-CAD4 program [10] and processed through the WINGX software package [11].

The crystalline structure of this compound was solved using the SIR 2014 program [12], which allowed the different atoms to be localized in the cell other than the hydrogen atoms. At this stage, an empirical psi-scan [13] absorption correction was applied.

The hydrogen atoms of the water molecules were found in a difference Fourier map and refined, using the SHELXL-2014 program [14], with restraint: $\mathrm{d}(\mathrm{O}-\mathrm{H})=1.11(1) \AA . \mathrm{H}$ atoms of the 5-methylbenzimidazole cation attached to carbon and nitrogen were fixed using the AFIX 43 instruction authorized by the SHELXL-2014 program. Those attached to carbon atoms were placed in calculated positions with $\mathrm{C}-\mathrm{H}$ distance of $0.96 \AA$, while those attached to nitrogen were restrained with $\mathrm{d}(\mathrm{N}-\mathrm{H})=0.86 \AA$. Their anisotropic thermal parameters were maintained $\operatorname{Uiso}(\mathrm{H})=1.2 \mathrm{Ueq}(\mathrm{X})(\mathrm{X}=\mathrm{C}$ or $\mathrm{N})$. After final refinement, a Fourier-Difference examination reveals no significant peak. All graphic representations have been developed via the Diamond version 3.2 program [15].

The crystallographic data, the experimental details of the data collection and the results of refinement of the crystal structure are summarized in Table 1.

\subsection{X-Ray Powder Diffraction}

The PXRD diagram was obtained at room temperature. The measurement was made with Bragg-Brentano geometry at $2 \theta$, in the range of $5^{\circ}$ to $70^{\circ}$ with a pitch of $0.02^{\circ}$.

The X-ray powder diffraction data of the $\left(\mathrm{C}_{8} \mathrm{H}_{9} \mathrm{~N}_{2}\right)_{3}\left[\mathrm{Al}\left(\mathrm{C}_{2} \mathrm{O}_{4}\right)_{3}\right] \cdot 3 \mathrm{H}_{2} \mathrm{O}$ sample was analyzed with the Rietveld technical refinement by means of GSAS-EXPGUI software [16] [17]. The final Rietveld plot is shown in Figure 1.

The peaks of the experimental diffractogram and those of the theoretical one are in a good agreement, which confirms the purity of that phase $\left(\mathrm{C}_{8} \mathrm{H}_{9} \mathrm{~N}_{2}\right)_{3}\left[\mathrm{Al}\left(\mathrm{C}_{2} \mathrm{O}_{4}\right)_{3}\right] \cdot 3 \mathrm{H}_{2} \mathrm{O}$. 
Table 1. Crystal and structure refinement data for the title compound: $\left(\mathrm{C}_{8} \mathrm{H}_{9} \mathrm{~N}_{2}\right)_{3}\left[\mathrm{Al}\left(\mathrm{C}_{2} \mathrm{O}_{4}\right)_{3}\right] \cdot 3 \mathrm{H}_{2} \mathrm{O}$.

\begin{tabular}{|c|c|}
\hline Chemical formula & $\left(\mathrm{C}_{8} \mathrm{H}_{9} \mathrm{~N}_{2}\right)_{3}\left[\mathrm{Al}\left(\mathrm{C}_{2} \mathrm{O}_{4}\right)_{3}\right] \cdot 3 \mathrm{H}_{2} \mathrm{O}$ \\
\hline Formula weight $\left(\mathrm{g} \cdot \mathrm{mol}^{-1}\right)$ & 744.60 \\
\hline Temperature (K) & 298 \\
\hline Crystal system; Space group & Monoclinic; $\mathrm{P} 2_{1} / \mathrm{c}$ \\
\hline $\mathrm{a}(\AA) ; \mathrm{b}(\AA) ; \mathrm{c}(\AA) ; \beta\left(^{\circ}\right)$ & $13.499(7) ; 14.872(9) ; 16.995(5) ; 91.44(3)$ \\
\hline Volume $\left(\AA^{3}\right) ; Z$ & $3411(3) ; 4$ \\
\hline Sample size $(\mathrm{mm})$ & $0.24 \times 0.15 \times 0.08$ \\
\hline Radiation, $\lambda,(\AA)$ & $\lambda=0.71073$ \\
\hline$\mu\left(\mathrm{mm}^{-1}\right)$ & 0.14 \\
\hline $\mathrm{F}_{000}$ & 1552 \\
\hline$\theta$ Range $\left({ }^{\circ}\right)$ & $2.0 \leq \theta \leq 27.2$ \\
\hline Scan mode & $\omega-2 \theta$ \\
\hline Absorption correction & psi-scan \\
\hline$T_{\min }, T_{\max }$ & $0.8948 ; 0.9999$ \\
\hline Number of reflections measured; & 8630 \\
\hline Independent reflections; $\mathrm{R}_{\mathrm{int}}$ & $7540 ; 0.0603$ \\
\hline Reflections with $[\mathrm{I}>2 \sigma(\mathrm{I})]$ & 3695 \\
\hline $\mathrm{R}\left(\mathrm{F}^{2}\right) ; \omega \mathrm{R}\left(\mathrm{F}^{2}\right) ; \mathrm{S}(\mathrm{GOOF})$ & $0.0782 ; 0.2472 ; 1.016$ \\
\hline$\Delta \rho_{\max }, \Delta \rho_{\min }\left(\mathrm{e} \cdot \AA^{-3}\right)$ & $0.63 ;-0.41^{*}$ \\
\hline
\end{tabular}

${ }^{*} \mathrm{CIF}$ file containing complete information about the structure of $\left(\mathrm{C}_{8} \mathrm{H}_{9} \mathrm{~N}_{2}\right)_{3}\left[\mathrm{Al}\left(\mathrm{C}_{2} \mathrm{O}_{4}\right)_{3}\right] \cdot 3 \mathrm{H}_{2} \mathrm{O}$ was deposited with the Cambridge Crystallographic Data Center (CCDC 1965815). The file is freely available upon request from the following web site: http://www.ccdc.cam.ac.uk/data_request/cif.

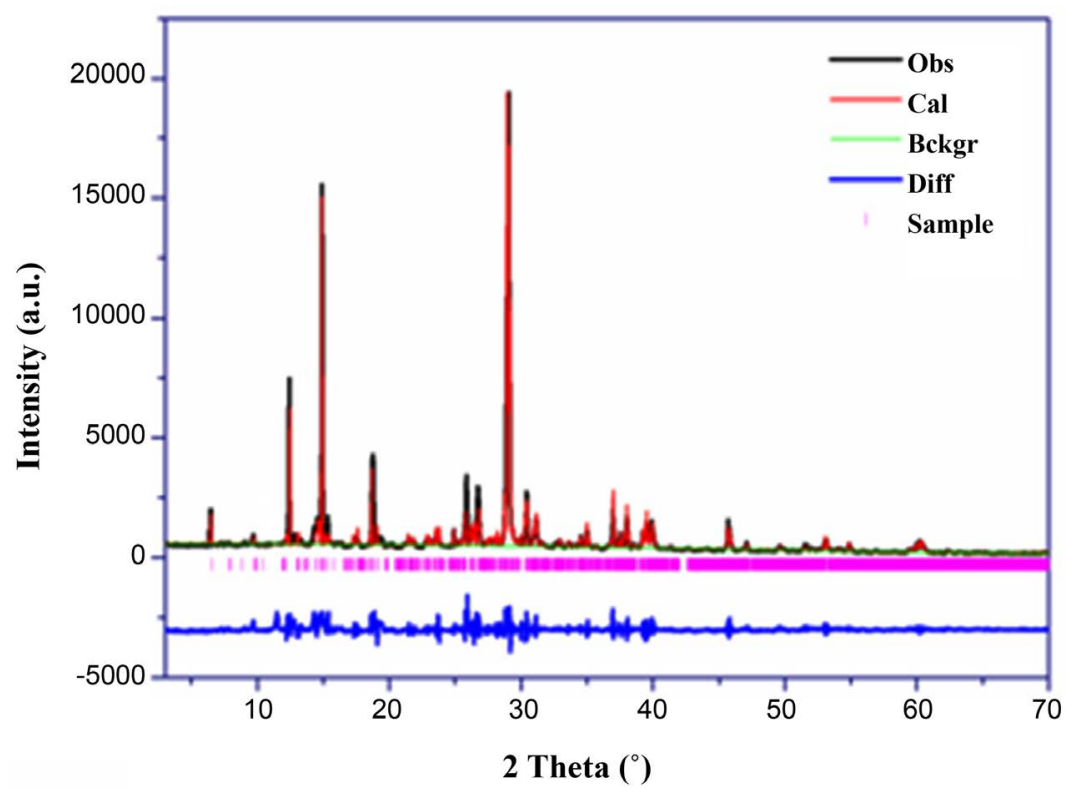

Figure 1. Experimental and calculated powder $\mathrm{X}$-ray diffraction patterns of $\left(\mathrm{C}_{8} \mathrm{H}_{9} \mathrm{~N}_{2}\right)_{3}\left[\mathrm{Al}\left(\mathrm{C}_{2} \mathrm{O}_{4}\right)_{3}\right] \cdot 3 \mathrm{H}_{2} \mathrm{O}$. 


\subsection{IR Spectrum of $\left(\mathrm{C}_{8} \mathrm{H}_{9} \mathrm{~N}_{2}\right)_{3}\left[\mathrm{Al}\left(\mathrm{C}_{2} \mathrm{O}_{4}\right)_{3}\right] \cdot 3 \mathrm{H}_{2} \mathrm{O}$}

The IR spectrum of the compound tris-(5-methylbenzimidazole) tris-(oxalato)-aluminate (III) trihydrateis is shown in Figure 2.

In the region of high frequencies, the bands at 3458 and $3100 \mathrm{~cm}^{-1}$ are due to the stretching vibrations of the $\mathrm{O}-\mathrm{H}$ and C-Haromatic bonds [18]. Harmonic bands of weak deformations are observed between 2000 and $1980 \mathrm{~cm}^{-1}$ [19]. The band at $1686 \mathrm{~cm}^{-1}$ is assigned to the $\mathrm{C}=\mathrm{O}$ stretching mode of the oxalate ligands [20].

The absorption band at $1419 \mathrm{~cm}^{-1}$ is attributed to the $\mathrm{C}=\mathrm{C}$ and $\mathrm{C}-\mathrm{C}$ stretching modes of the 5-methylbenzimidazole ring [21]. The weak bands at 1295 and 813 $\mathrm{cm}^{-1}$ are attributed to the $v\left(\mathrm{C}-\mathrm{N}_{\text {aromatic }}\right)$ and $\delta(\mathrm{C}-\mathrm{H})$ modes [22].

The absorption band located at $722 \mathrm{~cm}^{-1}$ corresponds to the $\delta(\mathrm{N}-\mathrm{H})$ mode [23]. The band at $467 \mathrm{~cm}^{-1}$ is assigned to the $v(\mathrm{Al}-\mathrm{O})$ mode [24].

\subsection{UV-Vis Spectrum of $\left(\mathrm{C}_{8} \mathrm{H}_{9} \mathrm{~N}_{2}\right)_{3}\left[\mathrm{Al}\left(\mathrm{C}_{2} \mathrm{O}_{4}\right)_{3}\right] \cdot 3 \mathrm{H}_{2} \mathrm{O}$}

The obtained UV-Vis Spectrum for the studied tris-(5-methylbenzimidazole) tris-(oxalato)-aluminate(III) trihydrate salt is depicted in Figure 3. The UV-Vis spectrum reveals two distinct absorption bands around 273 and $279 \mathrm{~nm}$ attributed, respectively, to the $\pi-\pi$ and $\pi-\pi^{*}$ absorption bands of the 5 -methylbenzimidazole cations [25]. Thus, the value of the energy of optical gaps is obtained by the Tauc relation [26]:

$$
(\alpha h v)^{n}=B\left(h v-E_{g}\right)
$$

$\alpha$ : the absorption coefficient, $h v$ : the energy of the incident photon, $B$ : a constant that depends on the energy, $E_{g}$ : the optical gap energy, $n$ : a constant that takes different values depending on the type of electronic transition. The experimental band-gap energy $\left(E_{g}\right)$ estimated by extrapolation of the linear part is about 2.88 $\mathrm{eV}$ (Figure 4). This band-gap value shows that this compound exhibits semiconductor behavior (the gap energy is less than $4 \mathrm{eV}$ ).

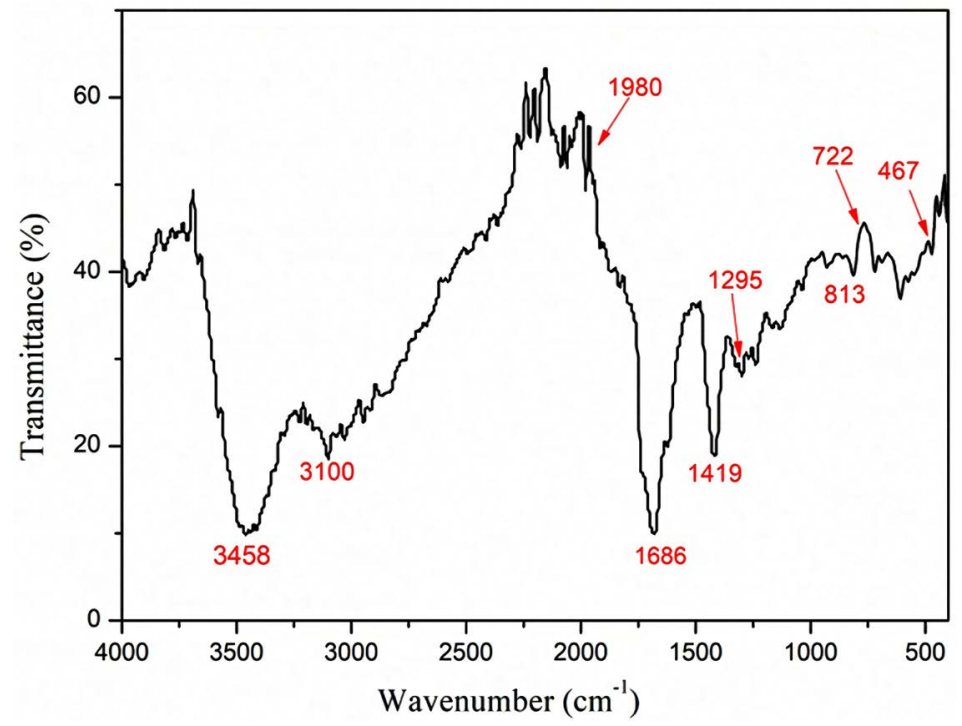

Figure 2. IR spectrum of the compound $\left(\mathrm{C}_{8} \mathrm{H}_{9} \mathrm{~N}_{2}\right)_{3}\left[\mathrm{Al}\left(\mathrm{C}_{2} \mathrm{O}_{4}\right)_{3}\right] \cdot 3 \mathrm{H}_{2} \mathrm{O}$. 


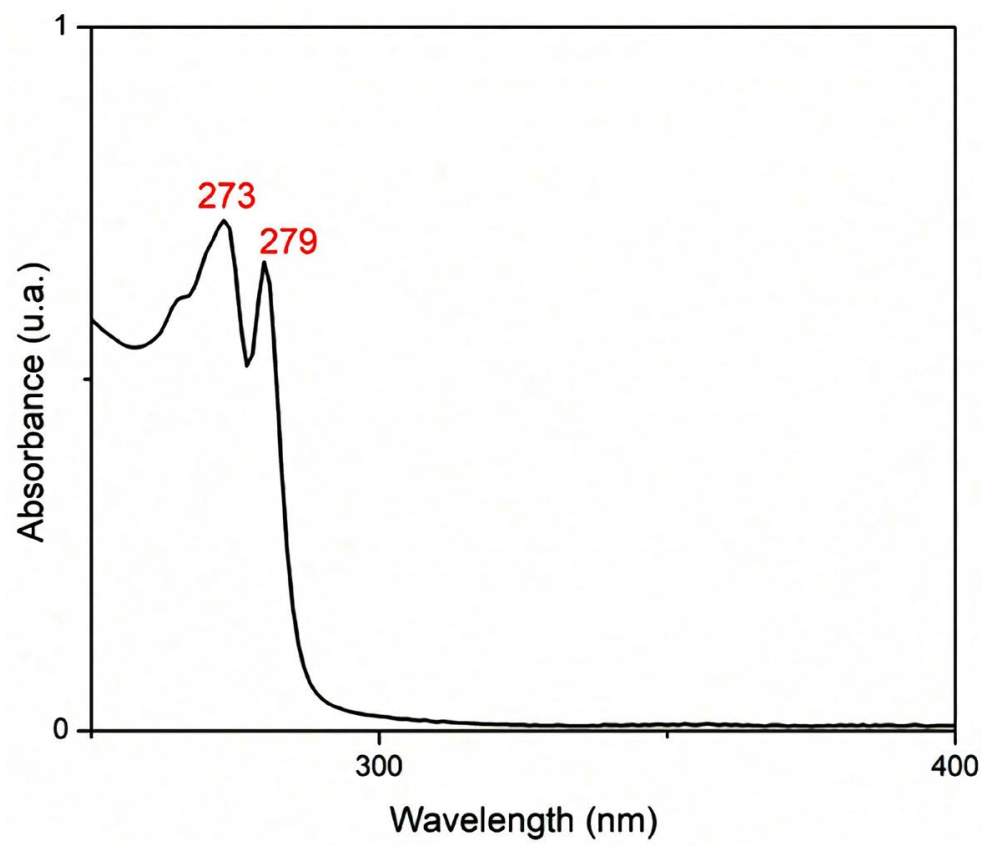

Figure 3. UV-Vis spectrum of the compound: $\left(\mathrm{C}_{8} \mathrm{H}_{9} \mathrm{~N}_{2}\right)_{3}\left[\mathrm{Al}\left(\mathrm{C}_{2} \mathrm{O}_{4}\right)_{3}\right] \cdot 3 \mathrm{H}_{2} \mathrm{O}$.

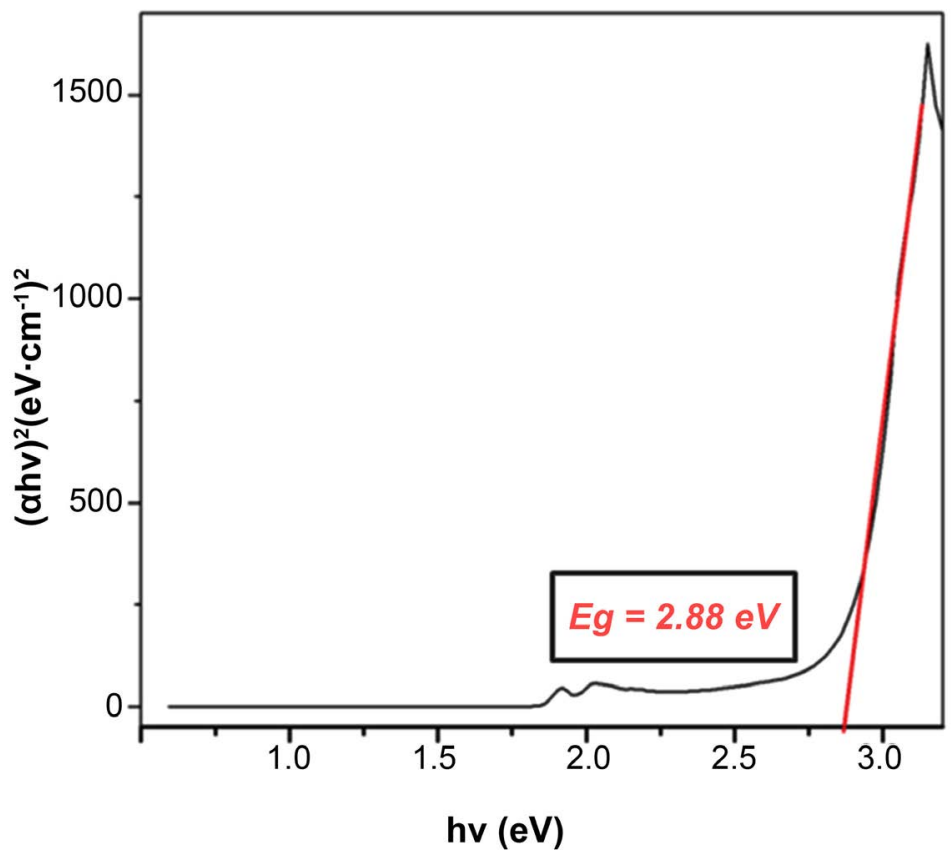

Figure 4. The inset shows the experimental energy band gap obtained by extrapolation of the linear part.

\subsection{Thermal Analysis of the Compound $\left(\mathrm{C}_{8} \mathrm{H}_{9} \mathrm{~N}_{2}\right)_{3}\left[\mathrm{Al}\left(\mathrm{C}_{2} \mathrm{O}_{4}\right)_{3}\right] \cdot 3 \mathrm{H}_{2} \mathrm{O}$}

The thermogram analysis (TGA-DTA) of $\left(\mathrm{C}_{8} \mathrm{H}_{9} \mathrm{~N}_{2}\right)_{3}\left[\mathrm{Al}\left(\mathrm{C}_{2} \mathrm{O}_{4}\right)_{3}\right] \cdot 3 \mathrm{H}_{2} \mathrm{O}$ (Figure 5) shows that the percentage of the experimental mass loss is in the order of $6.90 \%$, which is calculated in the order of $7.25 \%$. Indeed, the latter is equivalent to starting from three salvation molecules of water at a temperature between $50^{\circ} \mathrm{C}$ to $85^{\circ} \mathrm{C}$. This step is characterized by two endothermic peaks in a temperature 


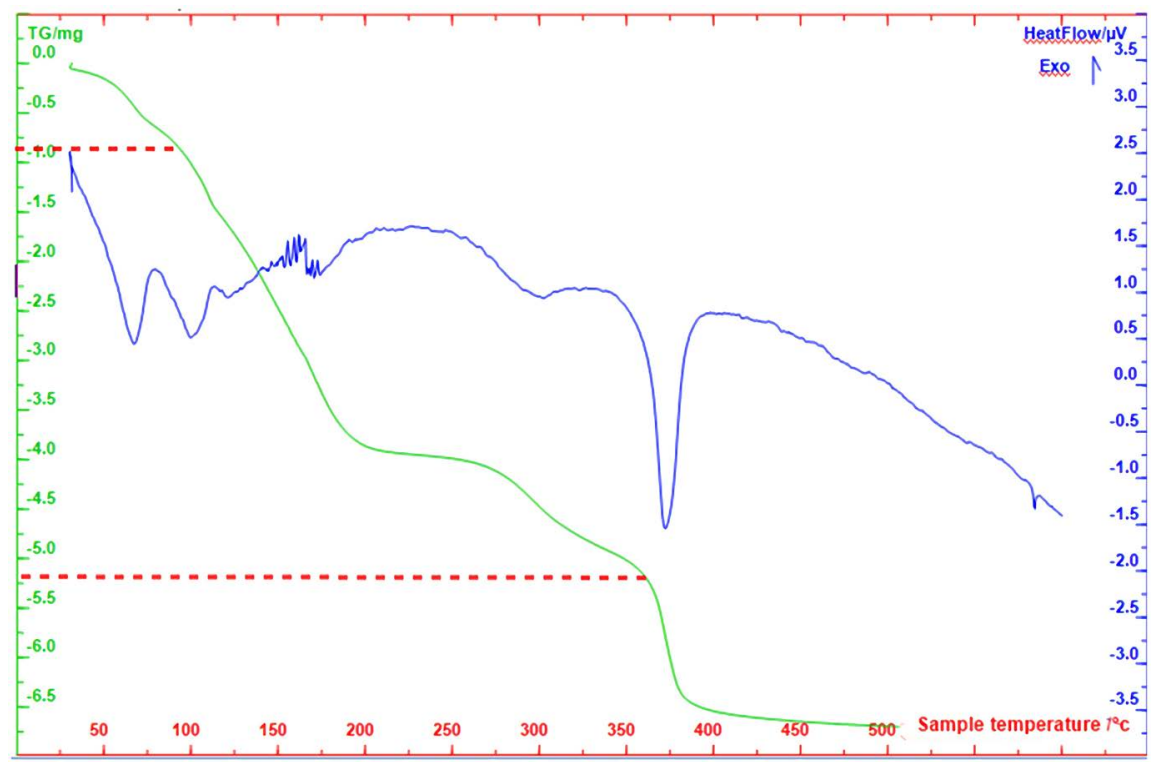

Figure 5. Thermal Analysis of the Title compound: $\left(\mathrm{C}_{8} \mathrm{H}_{9} \mathrm{~N}_{2}\right)_{3}\left[\mathrm{Al}\left(\mathrm{C}_{2} \mathrm{O}_{4}\right)_{3}\right] \cdot 3 \mathrm{H}_{2} \mathrm{O}$.

range of $65^{\circ} \mathrm{C}-120^{\circ} \mathrm{C}$. At around $120^{\circ} \mathrm{C}$, there is a second loss which reflects the decomposition of the organic part and oxalate [\% calculated, 59.49 (experimental\%, 53.86)]. A last loss of mass phenomenon is observed at $350^{\circ} \mathrm{C}$, which corresponds to the conversion of $\mathrm{Al}_{2}\left(\mathrm{CO}_{3}\right)_{3}$ to $\mathrm{Al}_{2} \mathrm{O}_{3}$ with the departure of $\mathrm{CO}_{2}[\%$ calc, 6.01 (Experimental \%, 7.95)]. This step is characterized by an endothermic peak at $375^{\circ} \mathrm{C}$.

\section{Description of the Structure}

The asymmetric unit of the tris-(5-methylbenzimidazole) tris-(oxalato)-aluminate (III) trihydrate compound is formed by three $\left(\mathrm{C}_{8} \mathrm{H}_{9} \mathrm{~N}_{2}\right)^{+}$cations, one $\left[\mathrm{Al}\left(\mathrm{C}_{2} \mathrm{O}_{4}\right)_{3}\right]^{3-}$ anion, and three water crystallization's molecules (Figure 6).

The central atom of the anionic moiety is hexacoordinated by six oxygen atoms from three chelating oxalate (Figure 7). The central ion $\mathrm{Al}^{3+}$ is at $1.0772(2) \AA$ in the equatorial plane defined by four atoms (O1, O2, O4 and O5), it's also defined by three atoms $(\mathrm{O} 3, \mathrm{Al}, \mathrm{O} 6)$ located in axial position.

The aluminum is in the $(+3)$ oxidation state. This was confirmed by the bond valence sum calculations (Table 2) according to Brown [27].

The projection of the structure in the [010] direction shows that the crystalline stack of the compound is an alternation of anionic layers between which are inserted organic cations and free water molecules (Figure 8).

A detailed examination of the hydrogen bonds of the crystalline structure of the compound $\left(\mathrm{C}_{8} \mathrm{H}_{9} \mathrm{~N}_{2}\right)_{3}\left[\mathrm{Al}\left(\mathrm{C}_{2} \mathrm{O}_{4}\right)_{3}\right] \cdot 3 \mathrm{H}_{2} \mathrm{O}$ revealed the existence of two types of intermolecular interactions considered strong $(\mathrm{O}-\mathrm{H} . . . \mathrm{O})$ and $(\mathrm{N}-\mathrm{H} \ldots \mathrm{O})$ connecting complex anions, organic cations and water molecules (Figure 9). Indeed, the complex anions $\left[\mathrm{Al}\left(\mathrm{C}_{2} \mathrm{O}_{4}\right)_{3}\right]^{3-}$ act as acceptors via their oxygen atoms and the organic cations $\left(\mathrm{C}_{8} \mathrm{H}_{9} \mathrm{~N}_{2}\right)^{+}$contribute to these intermolecular interactions via their nitrogen atoms as donors. 


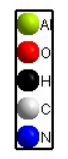

$8^{014}$
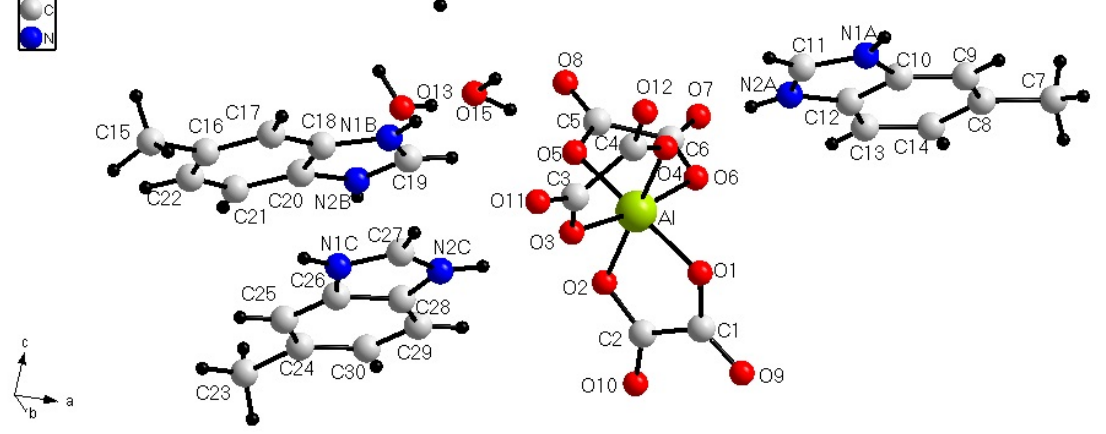

Figure 6. Asymmetric unit of $\left(\mathrm{C}_{8} \mathrm{H}_{9} \mathrm{~N}_{2}\right)_{3}\left[\mathrm{Al}\left(\mathrm{C}_{2} \mathrm{O}_{4}\right)_{3}\right] \cdot 3 \mathrm{H}_{2} \mathrm{O}$.

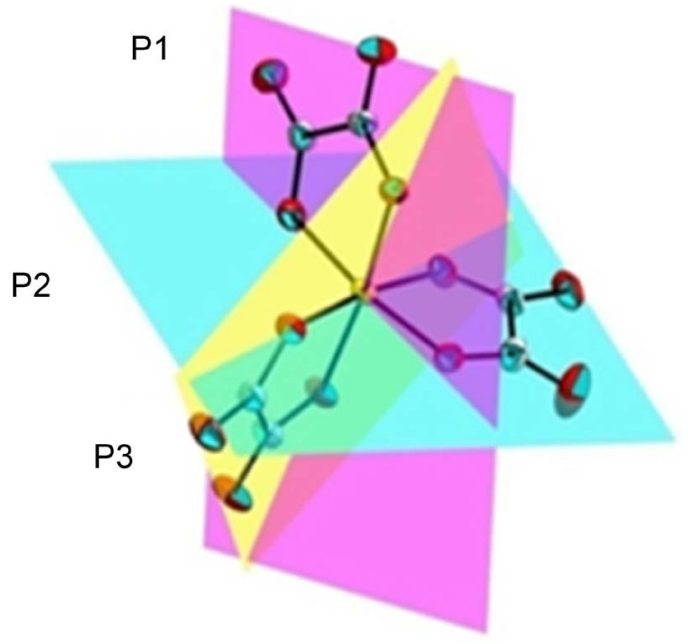

Figure 7. Representation of $\mathrm{AlO}_{6}$ octahedral geometry in the complex anion $\left[\mathrm{Al}\left(\mathrm{C}_{2} \mathrm{O}_{4}\right)_{3}\right]^{3-}$.

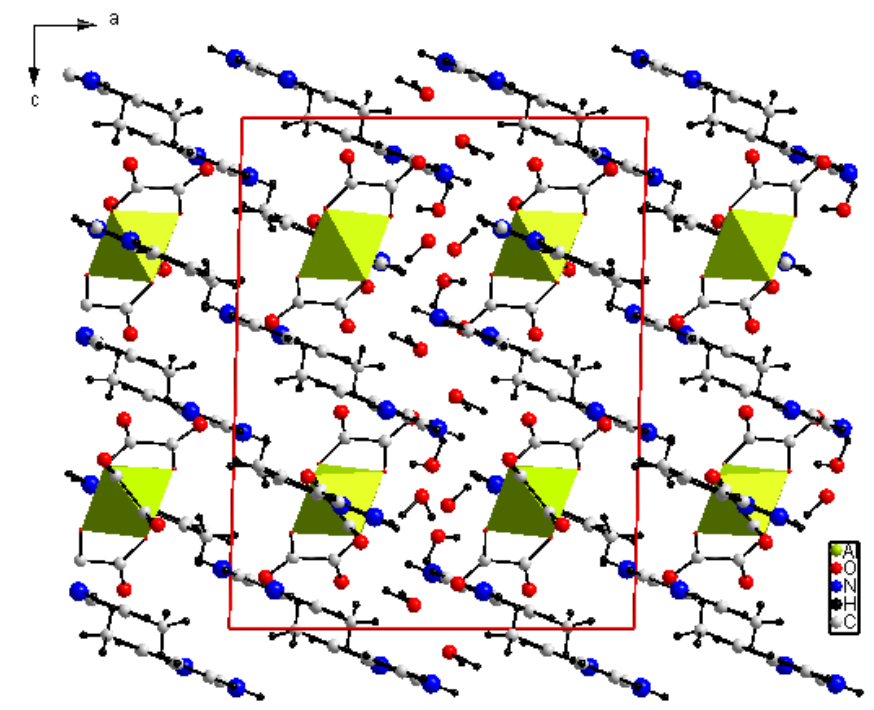

Figure 8. Projection of the structure, in the [010] direction, of $\left(\mathrm{C}_{8} \mathrm{H}_{9} \mathrm{~N}_{2}\right)_{3}\left[\mathrm{Al}\left(\mathrm{C}_{2} \mathrm{O}_{4}\right)_{3}\right] \cdot 3 \mathrm{H}_{2} \mathrm{O}$ compound. 
Table 2. Interatomic Distances ( $\AA$ ) and Bond Values Sum (BVS) in the $\mathrm{AlO}_{6}$ Octahedron.

\begin{tabular}{ccc}
\hline & Interatomic Distances $\AA$ Bond Valence Sum $(\mathrm{BVS})^{*}$ \\
\hline $\mathrm{Al}-\mathrm{O} 1$ & $1.8567(3)$ & 0.5735 \\
$\mathrm{Al}-\mathrm{O} 2$ & $1.8778(3)$ & 0.5417 \\
$\mathrm{Al}-\mathrm{O} 3$ & $1.8885(3)$ & 0.5263 \\
$\mathrm{Al}-\mathrm{O} 4$ & $1.8923(3)$ & 0.5209 \\
$\mathrm{Al}-\mathrm{O} 5$ & $1.9011(3)$ & 0.5087 \\
$\mathrm{Al}-\mathrm{O} 6$ & $1.9072(3)$ & 0.5004
\end{tabular}

$<\mathrm{d}(\mathrm{Al}-\mathrm{O})>\quad 1.8872(3)$
$*:\left(\mathrm{S}=\Sigma \mathrm{si}=\Sigma \exp \left[\left(\mathrm{R}_{0}-\mathrm{R}_{\mathrm{i}}\right) / \mathrm{B}\right] ; \mathrm{B}=0.37\right.$.

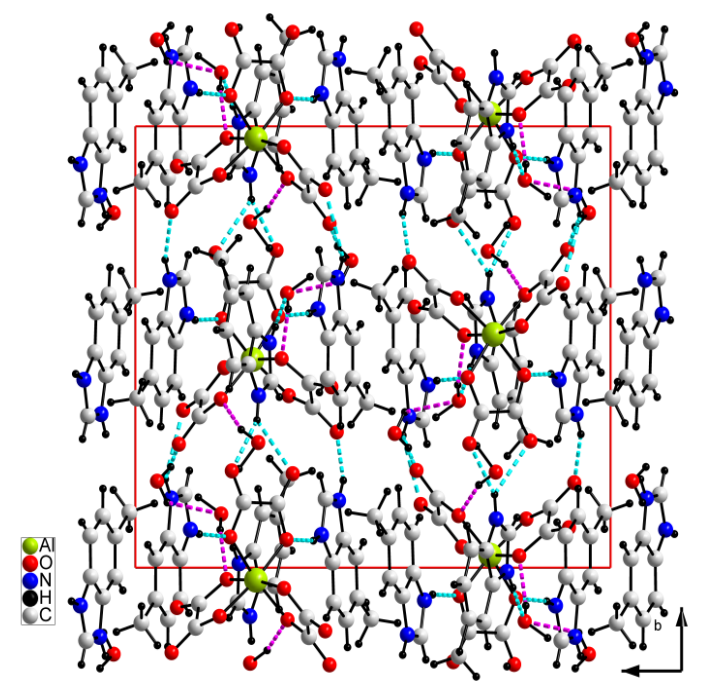

Figure 9. Representation of hydrogen bonds in the $\left(\mathrm{C}_{8} \mathrm{H}_{9} \mathrm{~N}_{2}\right)_{3}\left[\mathrm{Al}\left(\mathrm{C}_{2} \mathrm{O}_{4}\right)_{3}\right] \cdot 3 \mathrm{H}_{2} \mathrm{O}$ compound.

Two types of interaction $\pi$ - $\pi$ and $\pi-\pi^{*}(\mathrm{~d}=3.827(8) \AA$ and $\mathrm{d}=3.560(8) \AA)$ are observed between organic cations. The cationic framework can therefore be considered as a succession of dimers arranged head to tail (Figure 10).

\section{Hirshfeld Surface Analysis}

The Hirshfeld surface analysis [28] and the associated 2D-fingerprint plots were constructed from CIF file and were performed by the aid of Crystal Explorer program [29] in order to dissect crystal structures into non-covalent contacts [30] [31] and to clarify the intermolecular interactions in a visual manner. The crystal structure of (1) is a good example of the interplay of different molecular interactions. In order to analyze the various interactions that lead to the crystal structure, an intermolecular inter-contacts contributing to the Hirshfeld surface has been made.

The $\mathrm{d}_{\text {norm }}$ values were mapped over the Hirshfeld surface using different colours. Red regions represent closer contacts: O-H...O and N-H...O hydrogen bonds (Figure 11(a)). Blue regions represent longer contacts (no interactions) [32] [33]. 

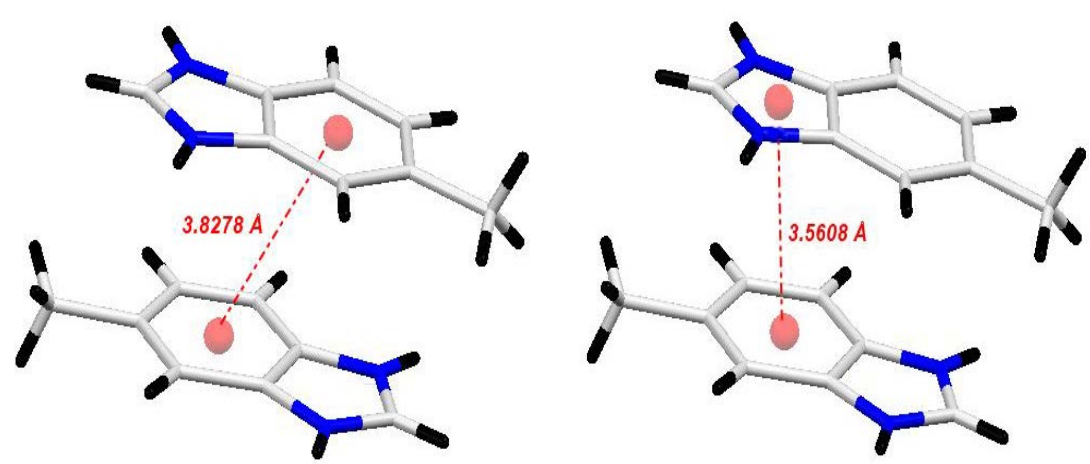

Figure 10. Representation of the cationic cycles and the interactions $\pi-\pi$ and $\pi-\pi^{*}$.

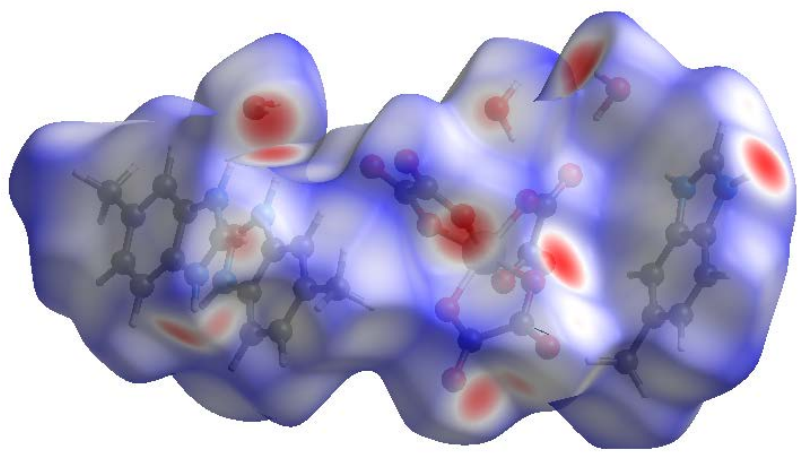

(a)

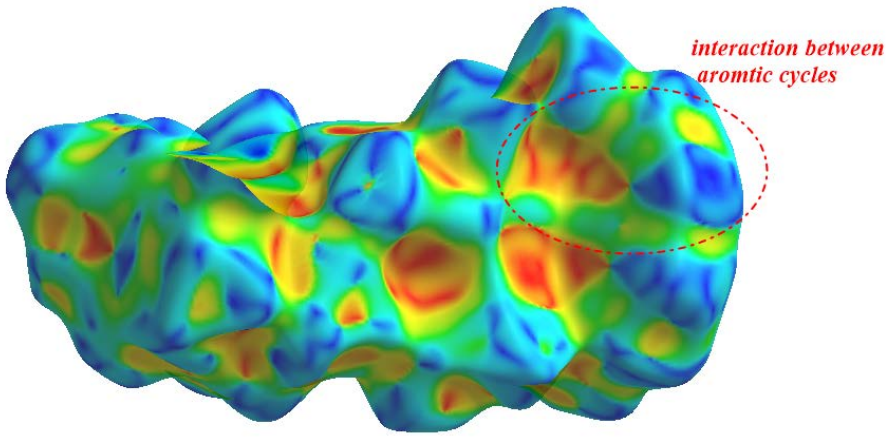

(b)

Figure 11. (a) View of the Hirshfeld surfaces mapped over $d_{\text {norm }}$ displaying the intermolecular interactions; (b) View of the Hirshfeld surfaces mapped overshape Index displaying the $\pi$ - $\pi$ interactions.

The shape-index map (Figure 11(b)) confirms the presence of the aromatic donor-acceptor interaction by the presence of two adjacent blue and orange triangles.

The 2D fingerprint plots view with the $\mathrm{d}_{\mathrm{e}}$ and $\mathrm{d}_{\mathrm{i}}$ distance scales are exposed on the graph axes. Figure 12 shows the most important interactions that assure the structure cohesion. The highest contribution occurs due to hydrogen contacts $\mathrm{O}-\mathrm{H} . . . \mathrm{O}(49.5 \%)$ and $\mathrm{C} \ldots \mathrm{H}(7.8 \%)$. The C...C contact in fingerprint plots (3.8\%) confirms the $\pi-\pi$ and $\pi-\pi^{*}$ stacking interactions between the rings of 5-methylbenzimidazole cations. 

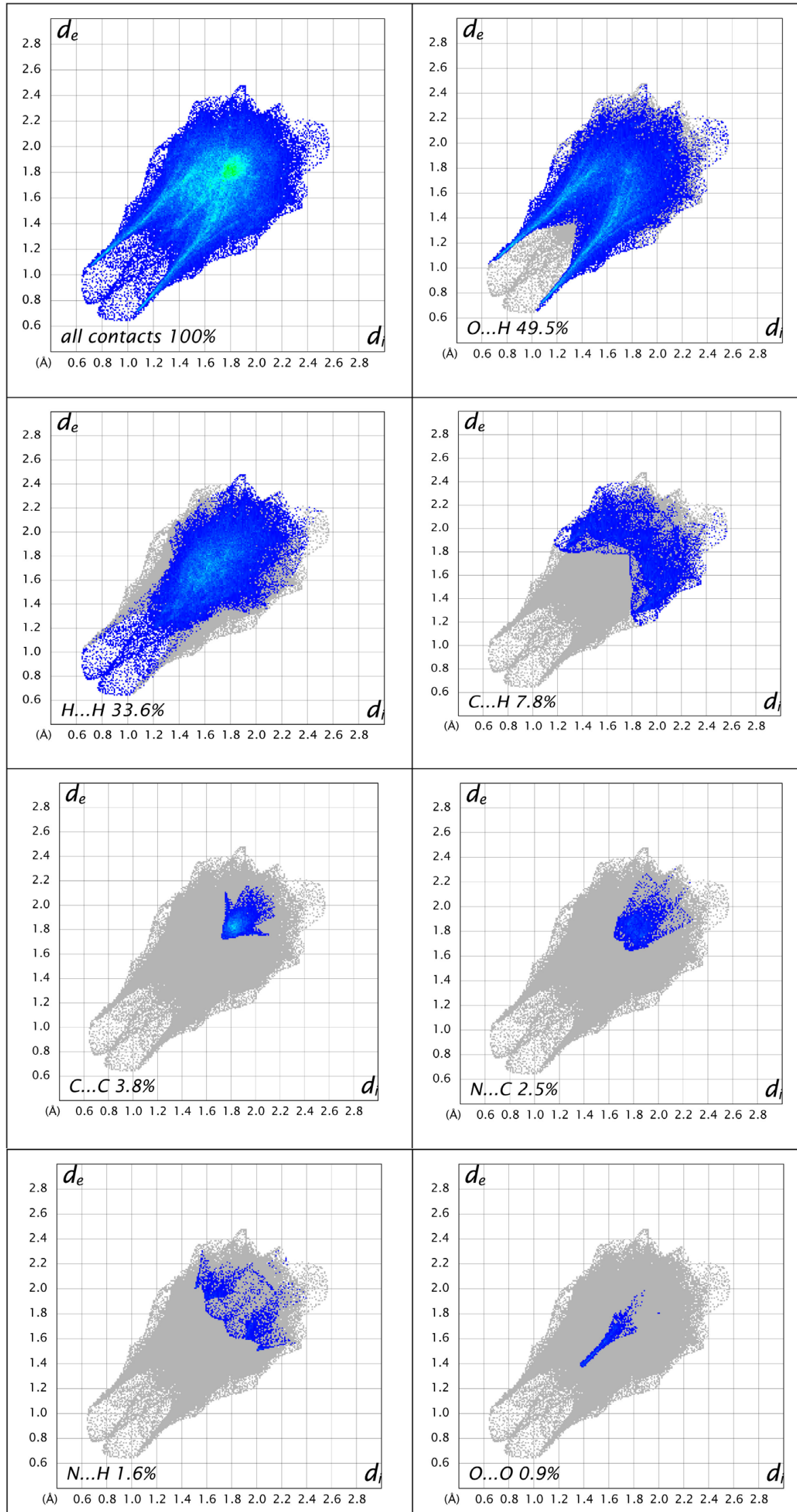


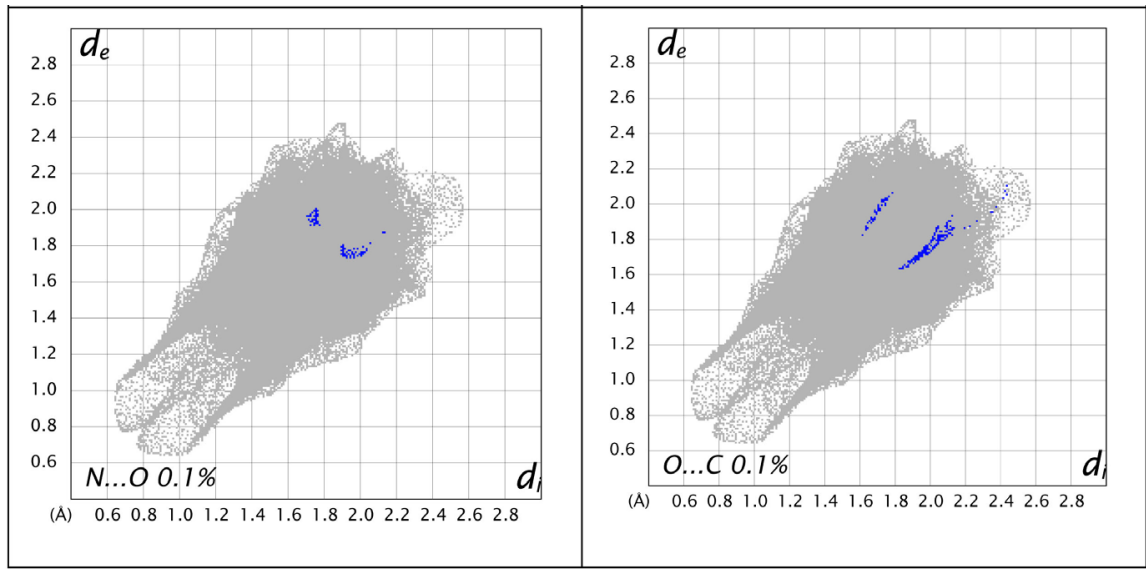

Figure 12. Full two-dimensional fingerprint plots showing all interactions, O-H...O (49.5\%), H...H (33.6\%), C...H (7.8\%), C...C (3.8\%), N... (2.5\%), N...H (1.6\%), O..O $(0.9 \%)$, N...O (0.1\%), O...C (0.1\%).

\section{Conclusion and Perspective}

A new aluminum (III) complex was synthesized by the slow evaporation method at room temperature. The crystalline structure of this compound has been characterized by single crystal X-ray diffraction and powder XRD. It is confirmed by IR, UV-visible spectroscopies, and thermal analysis TGA-DTA. Molecules of organic cations, complex anions and water are connected by hydrogen bonds $\mathrm{N}-\mathrm{H} \cdots \mathrm{O}$ and $\mathrm{O}-\mathrm{H} \cdots \mathrm{O}$, thus by $\pi-\pi$ and $\pi-\pi^{*}$ interactions between rings of 5-methylbenzimidazole to form a three-dimensional network. Investigation of intermolecular interactions via Hirshfeld surface analysis reveals that $\mathrm{O} \ldots \mathrm{H}$ contact intermolecular interaction is the most abundant in the crystal structure. In perspective, we will also try to synthesize new heteropolynuclear phases and study their magnetic and biological properties.

\section{Acknowledgements}

Financial support from the Ministry of Higher Education and Scientific Research of Tunisia is gratefully acknowledged.

\section{Conflicts of Interest}

The authors declare no conflicts of interest regarding the publication of this paper.

\section{References}

[1] Lindnes, E., Pautz, S. and Maustein, M. (1996) Dynamic, Reactivity and Catalytic Behavior of Pseudo-Undercoordinated Ruthenium and Rhodium Complexes Stabilized by Intramolecular Solvents. Coordination Chemistry Reviews, 155, 145-162. https://doi.org/10.1016/S0010-8545(96)90180-0

[2] Simpson, M.C. and Cole-Hamilton, D.J. (1996) Catalytic Applications of Rhodium Complexes Containing Trialkylphosphines. Coordination Chemistry Reviews, 155, 163-207. https://doi.org/10.1016/S0010-8545(96)90181-2 
[3] Zhang, S.S., Yan, Y.T., Zhang, W.Y., Fan, Y.K., Zhang, Y., Zhong, K. and Wang, Y.Y. (2019) Seven New Complexes Based on Various Coordination Modes of Bifunctional Ligand: Luminescent Sensing and Magnetic Properties. Inorganica Chimica Acta, 495, Article ID: 118971. https://doi.org/10.1016/j.ica.2019.118971

[4] Chylewska, A., Biedulska, M. and Makowski, M. (2017) Multi-Analytical Studies about Physico-Chemical Properties of Ni(II)-Vitamin B6 Coordination Compounds and Their CT-DNA Interactions. Journal of Molecular Liquids, 243, 771-780. https://doi.org/10.1016/j.molliq.2017.08.100

[5] Vengoechea-Gómez, F.A., Velázquez-Carmona, M.-A., Barroso, J., Merino, G. and Muñoz-Hernández, M.-A. (2018) Isomerization and Luminescent Properties of Schiff-Base Aluminum Complexes Containing 1H-Pyrrole-2-Carbaldehyde Moieties. Inorganica Chimica Acta, 482, 535-541. https://doi.org/10.1016/j.ica.2018.06.048

[6] Weisser, K., Stübler, S., Matheis, W. and Huisinga, W. (2017) Towards Toxicokinetic Modelling of Aluminium Exposure from Adjuvants in Medicinal Products. Regulatory Toxicology and Pharmacology, 88, 310-321. https://doi.org/10.1016/j.yrtph.2017.02.018

[7] Cui, X., Huo, M., Chen, C., Yu, Z., Zhou, C., Li, A., Qiao, B., Zhou, D. and Crittenden, J.C. (2018) Low Concentrations of Al(III) Accelerate the Formation of Biofilm: Multiple Effects of Hormesis and Flocculation. Science of the Total Environment, 634, 516-524. https://doi.org/10.1016/j.scitotenv.2018.03.376

[8] Boyer, J. (1976) Aluminium échangeable. ORSTOM, Paris, 259-269.

[9] Vaidhyanathan, R., Natarajan, S. and Rao, C.N.R. (2001) Synthesis of a Hierarchy of Zinc Oxalate Structures from Amine Oxalates. Journal of the Chemical Society, Dalton Transactions, 2, 699-706. https://doi.org/10.1039/b008571p

[10] Duisenberg, A.J.M. (1992) Indexing in Single-Crystal Diffractometry with an Obstinate List of Reflections. Journal of Applied Crystallography, 25, 92-96. https://doi.org/10.1107/S0021889891010634

[11] Farrugia, L. (2012) WinGX and ORTEP for Windows: An Update. Journal of Applied Crystallography, 45, 849-854. https://doi.org/10.1107/S0021889812029111

[12] Burla, M.C., Caliandro, R., Carrozzini, B., Cascarano, G.L., Cuocci, C., Giacovazzo, C., Mallamo, M., Mazzone, A. and Polidori, G. (2014) Crystal Structure Determination and Refinement via SIR2014. Journal of Applied Crystallography, 48, 306-309. https://doi.org/10.1107/S1600576715001132

[13] North, A.C.T., Phillips, D.C. and Mathews, F.S. (1968) A Semi-Empirical Method of Absorption Correction. Acta Crystallographica A, 24, 351-359. https://doi.org/10.1107/S0567739468000707

[14] Sheldrick, G.M. (2015) Crystal Structure Refinement with SHELXL. Acta Crystallographica C, 71, 3-8. https://doi.org/10.1107/S2053229614024218

[15] Brandenburg, K. (1998) Diamond, Version 3.2. Crystal Impact GbR, Bonn.

[16] Larson, A.C. and Von Dreele, R.B. (2000) General Structure Analysis System (GSAS). Report LAUR86-748, Los Alamos National Laboratory, Los Alamos.

[17] Toby, B.H. (2001) EXPGUI, Graphical User Interfaces for GSAS. Journal of Applied Crystallography, 34, 210-213. https://doi.org/10.1107/S0021889801002242

[18] Muthu, S. and Renuga, S. (2014) Vibrational Spectra and Normal Coordinate Analysis of 2-Hydroxy-3-(2-methoxyphenoxy) Propyl Carbamate. Spectrochimica Acta Part A, 132, 313-325. https://doi.org/10.1016/j.saa.2014.05.009

[19] Avram, M. and Mateescu, G.H. (1972) Infrared Spectroscopy, Application in Or- 
ganic Chemistry. Wiley-Interscience, Hoboken.

[20] Chun, J., Lee, Y., Pyo, S., Im, C., Kim, S.J., Yun, H. and Do, J. (2009) Synthesis, Structure, and Magnetic Properties of 1D Nickel Coordination Polymer $\mathrm{Ni}(\mathrm{en})(\mathrm{ox}) \cdot 2 \mathrm{H}_{2} \mathrm{O}$ (en = ethylenediamine; ox = oxalate). Bulletin of the Korean Chemical Society, 30, 1603-1606.

[21] Venkatesan, P., Thamotharan, S., Ilangovan, A., Liang, H. and Sundius, T. (2015) Crystal Structure, Hirshfeld Surfaces and DFT Computation of NLO Active (2E)-2(Ethoxycarbonyl)-3-[(1-methoxy-1-oxo-3-phenylpropan-2-yl)amino] prop-2-enoic acid. Spectrochimica Acta Part A, 153, 625. https://doi.org/10.1016/j.saa.2015.09.002

[22] Dobrzynska, D., Jerzykiewicz, L.B., Duczmal, M. and Wojciechowska, A. (2011) Synthesis, Structure, Magnetic and Spectroscopic Properties of Chromium(III) Complex with Quinoline-2-Carboxylate Ion. Polyhedron, 30, 2684-2689.

https://doi.org/10.1016/j.poly.2011.07.018

[23] Piro, O.E., Echeverría, G.A., Mercader, R.C., González-Baró, A.C. and Baran, E.J. (2016) Crystal Structure and Spectroscopic Behavior of Three New Tris-Oxalatoferrate(III) Salts. Journal of Coordination Chemistry, 69, 3715-3725. https://doi.org/10.1080/00958972.2016.1244670

[24] Lee, J.S., Kim, H.S., Park, N.K., Lee, T.J. and Kang, M. (2013) Low Temperature Synthesis of $\alpha$-Alumina from Aluminum Hydroxide Hydrothermally Synthesized Using $\left[\mathrm{Al}\left(\mathrm{C}_{2} \mathrm{O}_{4}\right)_{\mathrm{x}}(\mathrm{OH})_{\mathrm{y}}\right]$ Complexes. Chemical Engineering Journal, 230, 351-360. https://doi.org/10.1016/j.cej.2013.06.099

[25] Zhu, H., Liu, D., Li, Y.-H. and Cui, G.-H. (2019) Syntheses, Crystal Structures, and Photocatalytic Properties of Two Zinc(II) Coordination Polymers Based on Dicarboxylates and Flexible Bis(benzimidazole) Ligands. Polyhedron, 167, 44-50. https://doi.org/10.1016/j.poly.2019.04.011

[26] Tauc, J. and Menth, A. (1972) States in the Gap. Journal of Non-Crystalline Solids, 8, 569-585. https://doi.org/10.1016/0022-3093(72)90194-9

[27] Brown, I.D. (1992) Chemical and Steric Constraints in Inorganic Solids. Acta Crystallographica B, 48, 553-572. https://doi.org/10.1107/S0108768192002453

[28] Spackman, M.A. and Jayatilaka, D. (2009) Hirshfeld Surface Analysis. CrystEngComm, 11, 19-32. https://doi.org/10.1039/B818330A

[29] Rohl, A.L., Moret, M., Kaminsky Clabron, W.K., Mckinnon, J.J. and Kahr, B. (2008) Hirshfeld Surfaces Identify Inadequacies in Computations of Intermolecular Interactions in Crystals: Pentamorphic 1,8-Dihydroxyanthraquinone. Crystal Growth \& Design, 12, 4517-4525. https://doi.org/10.1021/cg8005212

[30] Spackman, M.A. and McKinnon, J.J. (2002) Fingerprinting Intermolecular Interactions in Molecular Crystals. CrystEngComm, 4, 378-392. https://doi.org/10.1039/B203191B

[31] McKinnon, J.J., Spackman, M.A. and Mitchell, A.S. (2004) Novel Tools for Visualizing and Exploring Intermol-Ecular Interactions in Molecular Crystals. Acta Crystallographica, 60, 627-668. https://doi.org/10.1107/S0108768104020300

[32] Ben Moussa, O., Chebbi, H. and Zid, M.F. (2019) Synthesis, Crystal Structure, Vibrational Study, Optical Properties and Hirshfeld Surface Analysis of Bis(2,6-diaminopyridinium) Tetrachloridocobaltate(II) Monohydrate. Journal of Molecular Structure, 1180, 72-80. https://doi.org/10.1016/j.molstruc.2018.11.077

[33] Garci, F., Ferjani, H., Chebbi, H., Ben Jomaa, M. and Zid, M.F. (2019) Crystal Structure, Hirshfeld Surface Analysis and Physicochemical Characterization of 
Bis-[4-(di-methyl-amino)-pyridinium] di- $\mu$-chlorido-bis[di-chlorido-mercurate(II)]. Acta Crystallographica Section E, 75, 1600-1606.

https://doi.org/10.1107/S2056989019013124 